\title{
Shadow Cell Differentiation: A Comparative Analysis of Modes of Cell Death with Apoptosis and Epidermal/Trichilemmal Keratinization
}

\author{
Toshitsugu Nakamura \\ Department of Diagnostic Pathology, Suwa Red Cross Hospital, Suwa, Japan
}

\section{Keywords}

Shadow cell differentiation · Epidermal keratinization · Trichilemmal keratinization .

Apoptosis · Pilomatricoma S Squamoid morule

\begin{abstract}
Shadow cells are characterized by an eosinophilic cytoplasm and a ghost-like nuclear contour; the cell shape is preserved, in spite of nuclear disappearance. Shadow cell nests (SCNs) are frequently observed in pilomatricoma (PMX), where the transitional cells immediately adjacent to SCNs often have a crescent-shaped nucleus showing fragmentation similar to that of apoptotic bodies. They show nuclear accumulation of beta-catenin and DNA double strand breaks (as revealed by in situ 3'-tailing reaction or immunohistochemistry for single-stranded DNA [ssDNA]), while they are negative for cleaved caspase-3 or cleaved lamin A, suggesting that shadow cell differentiation (SCD) is a caspase-independent programmed cell death. SCD can be differentiated from epidermal keratinization (EK) and trichilemmal keratinization (TK) based on the expression pattern of beta-catenin, ssDNA, and caspase-14/CD138. SCD is observed not only in PMX, but also sometimes in basal cell carcinomas, gonadal teratomas, and various extra-cutaneous carcinomas. In particular, SCNs are found in $24 \%$ of endometrial adenoacanthoma and are derived from squamoid morules. This establishes a link between basaloid cells in PMX and squamoid morules in endometrial adenoacanthomas as common precursors of shadow cells. Overall, it is suggested that SCD is different from, but partly similar to, apoptosis and that SCD and EK/TK should be differentiated from the standpoint of cell death/differentiation.




\section{Introduction}

Recent advances on the mechanisms of cell death have established that there are various forms of cell death, as characterized by their morphological features and/or molecular events. A classification/definition of cell death was first proposed by the Nomenclature Committee of Cell Death (NCCD) in 2005 [1, 2] and was thereafter revised in 2009 [3], 2012 [4], and 2018 [5]. The 1st and 2nd versions of the NCCD classification were based on morphological features $[2,3]$, whereas the classification was changed to one with a molecular basis in the 3rd version [4]. The molecular classification of cell death cannot be easily applied to lesions in routine diagnostic practice, whereas a tentative definition of cornification (keratinization) is described in the 3rd version (Table 1) [4]. Although the NCCD suggests keeping programmed cell death and terminal differentiation (TD) (including keratinization) discriminated from each other in the latest classification [5], the present review regards TD as a specific form of cell death, because it is our aim to discuss keratinization from the standpoint of cell death. An alternative classification of cell death by Leist and Jaattela [6] (Table 2) is simple and may be suitable for practical use.

TD is easily characterized by morphological analyses, but its molecular aspects are not sufficiently clear. Terminally differentiated cells are no longer proliferative and eventually undergo cell death, although they remain active for a certain period of time. TD includes the processes of differentiation toward lens fiber cells in the eye [7], erythropoiesis in the bone marrow [8], and cornification/keratinization, all of which are characterized by nuclear disappearance and a preserved cell contour [1]. Thus, skin is a good model for research on TD from the standpoint of cell death. Although keratinization usually refers to TD in the squamous epithelium of the epidermis (epidermal keratinization [EK]), it also includes some variants such as trichilemmal keratinization (TK) and shadow cell differentiation (SCD) [9], which are the processes of normal differentiation toward hair follicles and pathological differentiation toward hair, respectively [10]. The similarity and differences between these types of keratinization are not clear from the standpoint of cell death. This review will describe the morphological features and molecular events concerning cell death in various types of keratinization, especially SCD.

\section{Apoptosis versus Keratinization: A Brief Overview}

Apoptosis and keratinization have both been regarded as programmed cell death. These two processes are similar in that (a) they both show disintegration of the nucleus and DNA, and (b) destructive or inflammatory reactions do not occur in the surrounding tissue [1]. However, they are different from one another in terms of morphological changes as well as the underlying molecular mechanism of cell death (Table 3) $[1,11,12]$. The molecular characteristics of apoptosis, EK and TK are concisely described in the following paragraphs using current and classical knowledge in order to understand SCD.

\section{Apoptosis}

In the classic apoptotic process, externalization of phosphatidylserine on the outer cell membrane occurs initially and then both the nucleus (DNA and nuclear proteins) and cytoplasm (cytoskeletal proteins) are cleaved into small fragments, forming apoptotic bodies. Cells show chromatin condensation, DNA fragmentation (laddering), and cytoskeletal cleavage [13]. The major type of molecules involved in the apoptotic process are members of the caspase family [14], although caspase-independent apoptosis also occurs [15]. Caspases are synthesized in their inactive form and subsequently activated one after another in a cascade. The final activated molecule, cleaved caspase-3, releases the inhibitor of caspase- 
Table 1. Functional classification of regulated cell death modes [4]

Table 2. Four patterns of deaths: from apoptosis to necrosis [6]

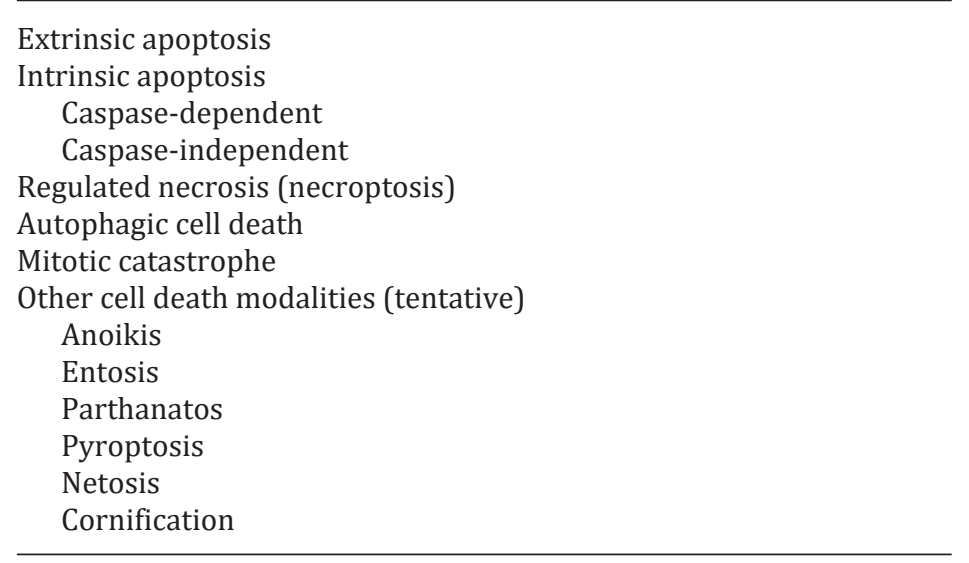

\begin{tabular}{ll}
\hline 1 & Apoptosis \\
2 & Apoptosis-like programmed cell death \\
3 & Necrosis-like programmed cell death \\
4 & Accidental necrosis/cell lysis \\
\hline
\end{tabular}

Table 3. Comparison of apoptosis with keratinization (modified from [1])

\begin{tabular}{lll}
\hline & Apoptosis & Keratinization \\
\hline Removal of dead cells & phagocytosis & desquamation \\
Cell membrane & intact/PS exposure & intact \\
Cell organelles & encapsulated & lysed \\
Nucleus & fragmentation & lost \\
$\quad$ Chromatin condensation & $(+)$ & - l) \\
$\quad$ DNA fragmentation & internucleosomal (ladder) & lost \\
$\quad$ TUNEL/ISTR & $(+)$ & $(-)$ \\
$\quad$ Nuclease & caspase-activated DNase & DNase 1L2/DNase 2 \\
Cytoskeletal proteins & cleaved (CK18/vimentin/actin) & crosslinked $\rightarrow$ degraded \\
Involved enzymes & caspase(-3) & transglutaminase, caspase-14, KLK \\
\hline
\end{tabular}

PS, phosphatidylserine; TUNEL, TdT-mediated uptake of nick end labeling; ISTR, in situ 3'-tailing reaction; CK18, cytokeratin 18; KLK, kallikrein-kinin family.

activated DNase (ICAD) from CAD, and the latter causes internucleosomal cleavage of DNA $[16,17]$.

Apoptotic bodies can be histochemically identified by terminal deoxynucleotidyl transferase (TdT)-mediated uptake of nick end labeling (TUNEL) [18]/in situ $3^{\prime}$-tailing reaction (ISTR) [19], both of which detects fragmented DNA (double strand breaks) by a 3 '-tailing reaction with labeled deoxynucleotides and TdT. Other markers include molecules activated during apoptosis (e.g., cleaved caspase-3 and CAD) [14, 17], fragmented DNA (e.g., singlestranded DNA [ssDNA]) [20], and cleaved intermediate filaments (e.g., cleaved lamin A [nuclear], cleaved cytokeratin 18, cleaved vimentin, and cleaved actin [cytoplasmic], etc.) [2123]. H2AX is a component of the histone octomer in nucleosomes and its phosphorylated form, $\gamma \mathrm{H} 2 \mathrm{AX}$, is generated in a 1:1 manner corresponding to the double strand breaks of DNA [24]. 


\section{Epidermal Keratinization}

In the epidermis, differentiation occurs from the basal layer to the spinous and granular layers, and terminally differentiated keratinocytes form a cornified layer (cornified squames). Basal cells sometimes undergo apoptosis as a result of various injurious stimuli such as UVB irradiation [25]; however, cornified keratinocytes are different from apoptotic cells. Although these cells are dead, they are not fragmented and the cell shape is preserved. Nuclear chromatin condensation or DNA laddering does not occur and the nuclei are lost without fragmentation. Histochemically, the cornified cells are non-reactive in TUNEL/ISTR [11]. Although the mechanism of nuclear degradation remains to be clarified, it has been suggested that DNase 1L2 and DNase 2 play important roles in DNA degradation during TD [26, 27].

The cornified keratinocytes maintain the cell shape by cytoskeletal rearrangement and the formation of a cornified envelope (CE). During TD, a gene cluster known as the "epidermal differentiation complex" (EDC) expresses involucrin and loricrin [28], which are crosslinked by transglutaminase [29] to form the CE at the cytoplasmic side of plasma membrane of the cornified cells. Profilaggrin is also generated by EDC expression and is cleaved into functional filaggrin [30], a main component of the keratohyalin granules in the granular layer. Filaggrin causes aggregation of keratin intermediate filaments inside the CE, providing mechanical strength. Profilaggrin is a direct substrate of caspase-14, which is expressed in the keratinizing epithelia (i.e., upper spinous layer to cornified layer of epidermis and hair follicles, but not in the nail matrix keratinocytes) and Hassal bodies of the thymus [31,32]. Thus, caspase-14 is a unique marker for EK.

The cornified cells remain connected by modified desmosomes termed corneodesmosomes [33] and work as a skin barrier. Corneodesmosomes are composed of corneodesmosin (CSDN), desmocollin I (DSC1), and desmoglein I (DSG1) [33, 34] and these corneodesmosomal proteins work as adhesive components, adhering cornified cells to one another. In a final event called desquamation, the cornified cells in the uppermost surface are degraded by kallikrein-kinin (KLK) family proteins such as KLK5 and KLK7 and/or by serine proteases such as cathepsin D and cathepsin V [34,35], and are subsequently gradually shed into the environment.

\section{Trichilemmal Keratinization}

In $\mathrm{TK}$, differentiation gives rise to the follicular outer root sheath (ORS) epithelium showing abrupt keratinization without the formation of a granular cell layer. Although not specific for TK, CD138 (syndecan-1), a unique marker whose expression is associated with the hair cycle, is of note. It is a cell surface glycoprotein that mediates cell adhesion and cell-cell/ cell-matrix interactions. It is expressed throughout the entire layer of the epidermis except for the keratinizing layer, as well as in the ORS of the anagen stage hair follicles; however, its expression is diminished in catagen and telogen phases [36, 37]. We recently found that EK and TK can be differentiated from each other by immunohistochemical staining for caspase-14 and CD138 [9]; the keratinizing components are caspase-14(+)/CD138(-) in epidermal cysts (showing EK), and caspase-14(-)/CD138(+) in trichilemmal cysts (showing TK) (Fig. 1).

\section{Shadow Cell Differentiation}

Shadow cells are characterized by an ovoid or polyhedral eosinophilic cytoplasm with ghost-like nuclear contour; i.e., nuclei gradually disappear during SCD. Although they are dying cells, the cytoplasm is well preserved. SCD is regarded as a pathological counterpart of differentiation towards hair; the morphological features of the normal hair shaft are different from those of shadow cells in that the nucleus is preserved in hair cells [10]. 


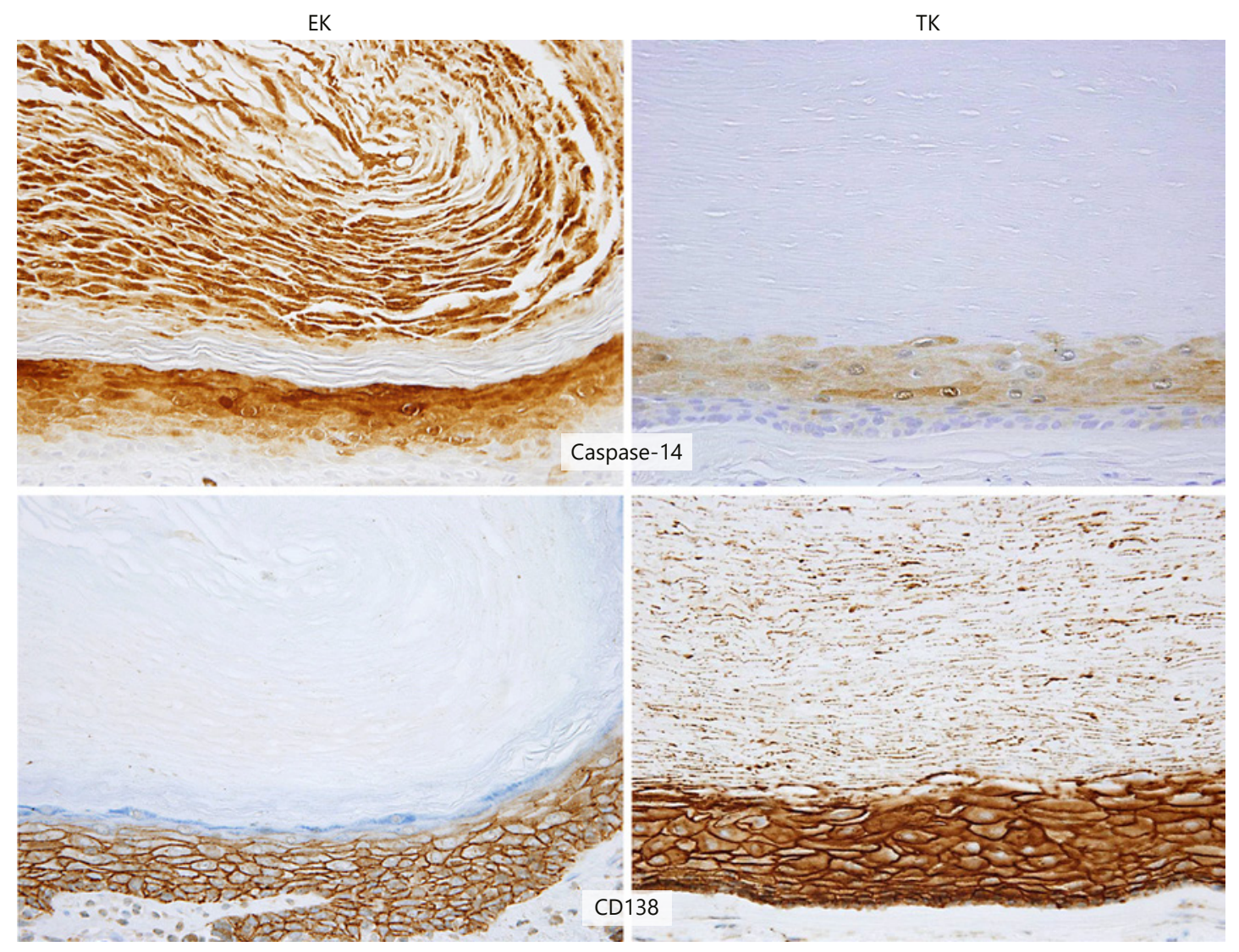

Fig. 1. Immunohistochemical differentiation of epidermal keratinization (EK) and trichilemmal keratinization (TK). EK cells (in epidermal cysts) are caspase-14(+)/CD138(-), whereas TK cells (in trichilemmal cysts) are caspase-14(-)/CD138(+).

SCD is most commonly observed in PMX, craniopharyngiomas, and calcifying odontogenic cysts. It is also observed in basal cell carcinoma (BCC), some gonadal or extragonadal teratomatous tumors, and some visceral carcinomas (see below). In these tumors, most of the cases show nuclear accumulation of beta-catenin $[38,39]$, which typically indicates CTNNB1 gene mutation [40]. Beta-catenin is a dual-functional protein according to its localization; submembrane-localized protein plays an important role in cadherin-mediated cell adhesion system, and nuclear accumulated protein acts as a key component of the Wnt/beta-catenin/ Tcf-Lcf (lymphoid enhancer factor) pathway [41]. The Wnt signal transduction pathway is activated not only in normal hair follicle matrix cells to induce differentiation towards the hair shaft, but also in various tumors with the CTNNB1 gene mutation. Thus, tumors showing SCD usually reveal activation of the Wnt signaling pathway [40].

\section{SCD in PMX}

In PMX, tumor cells with proliferative activity are basaloid cells, mainly present in the periphery of the nodules. There are various components showing TD or cell death inside the nodules by one of the following routes [42, 43]: (a) SCD, the main route of cell death/differentiation, (b) conventional apoptosis, and (c) EK/TK (Fig. 2). A transition between these components is not obvious. Apart from old PMX, conventional apoptosis can be observed as a minor component among shadow cell nests (SCNs). Although the components showing EK are histologically inconspicuous in PMX, they are observed in most cases, as highlighted by 

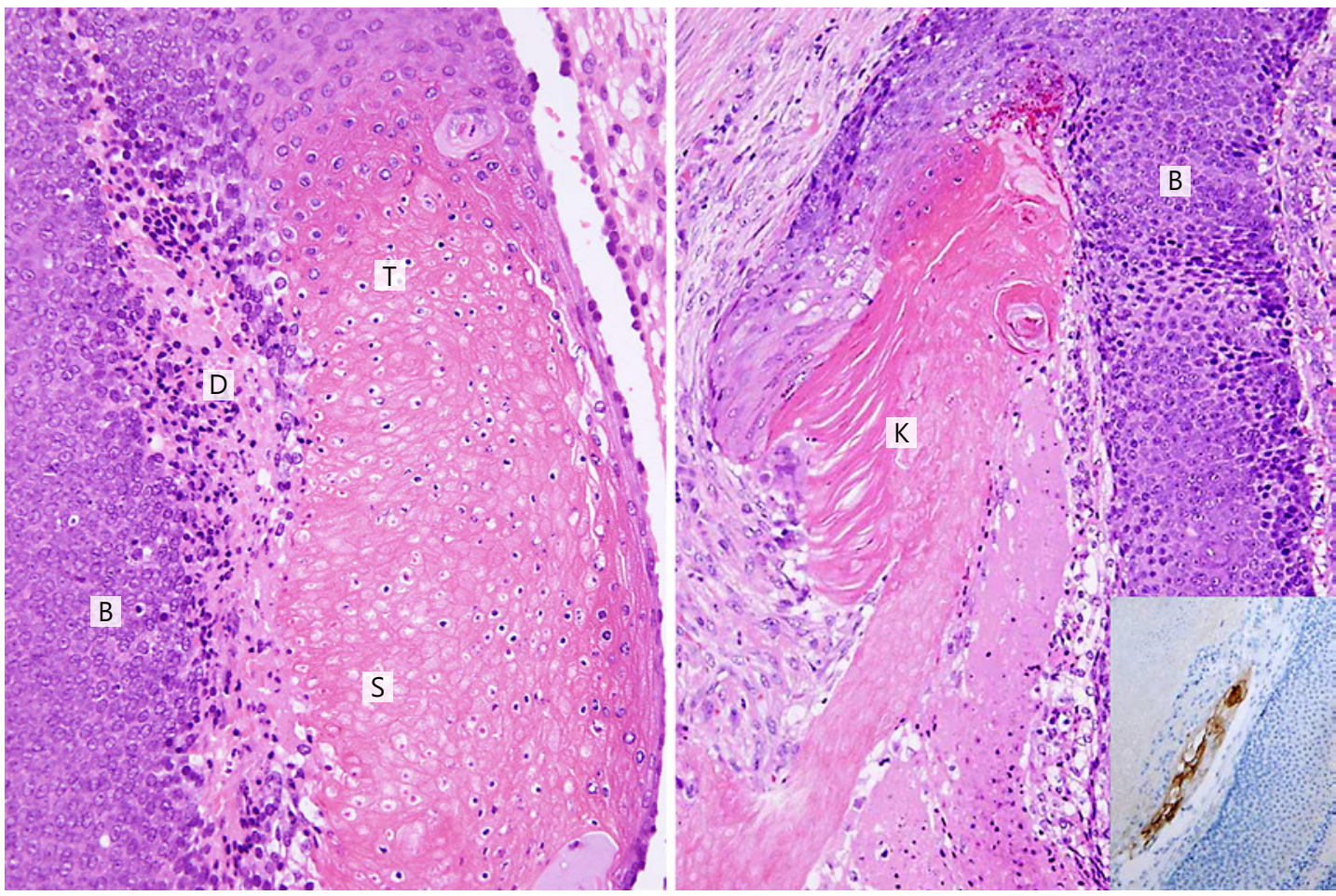

Fig. 2. Modes of cell death in pilomatricoma, showing shadow cell differentiation and conventional apoptosis (left) and epidermal keratinization (EK) (right) (H\&E stain). Inset Immunostaining for corneodesmosin indicates EK. B, basaloid cells; T, transitional cells; S, shadow cells; D, amorphous debris containing apoptotic bodies; K, epidermal keratinization.
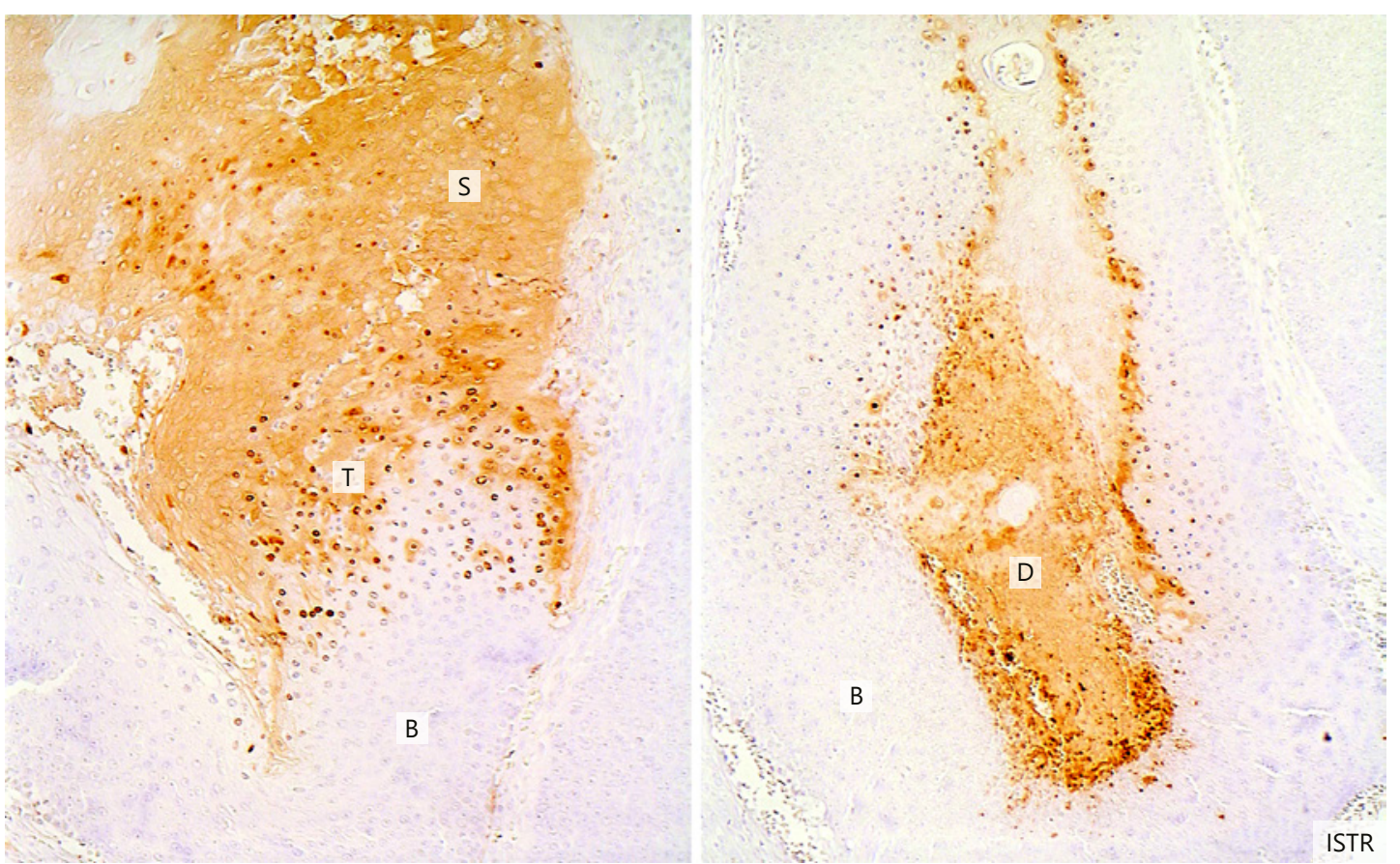

Fig. 3. In situ $3^{\prime}$-tailing reaction for detection of DNA double strand breaks in pilomatricoma. Transitional cells (left) and apoptotic bodies (right) are labeled. B, T, S, D, see Fig. 2. 
Fig. 4. Transitional cells in pilomatricoma often have crescentshaped nuclei, similar to apoptotic bodies in part (H\&E stain).

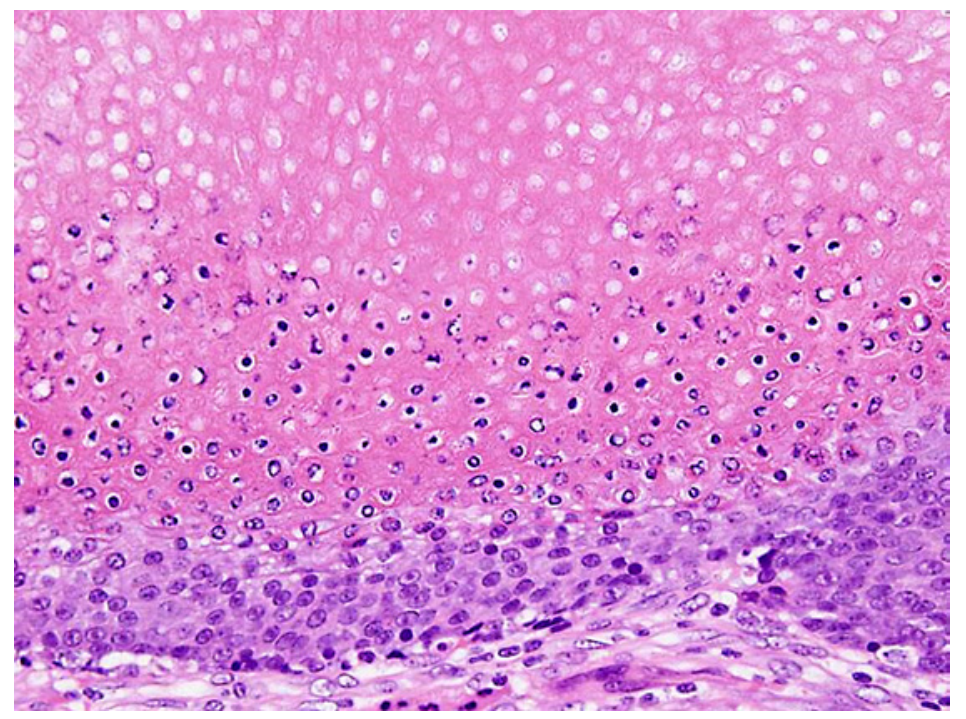

immunostaining for CSDN, DSC1, and DSG1 (Fig. 2, inset). TK is rarely observed in PMX [43]. The nodule containing equal amounts of SCD and EK components is called an infundibular matrix cyst or hybrid cyst [44].

Conventional apoptosis can be observed as amorphous debris immediately adjacent to basaloid cell nests, and apoptotic bodies among SCNs are TUNEL/ISTR positive (Fig. 3) [42]. SCNs are derived from the basaloid cell layer via transitional cells. A small number of transitional cells immediately adjacent to SCNs have crescent-shaped nuclei with fragmentation similar to that of apoptotic bodies (Fig. 4), suggesting that SCD and apoptosis may compose a sequential chain of cell death pathways. The transitional cells are labeled by TUNEL/ISTR [42] (Fig. 3), immunoreactive for ssDNA and $\gamma \mathrm{H} 2 \mathrm{AX}$, but not reactive for cleaved caspase-3 or cleaved lamin A [9] (Fig. 5). These findings indicate that apoptosis-executing molecules are not activated, but that DNA double strand breaks occur during SCD. SCD might be similar to, but partially different, from apoptosis; it might be possible that SCD is a form of caspase-independent cell death. On the other hand, transitional cells in PMX are negative for markers for conventional keratinization such as caspase-14 and CD138. SCD, EK, and TK are differentiated by their immunoreactivity for caspase-14 and CD138 [9] (Fig. 1). In addition, nuclear accumulation of beta-catenin is observed in the transitional cells during SCD, but not in the cells showing EK/TK, suggesting that SCD is a distinct process from EK/TK. As it has been demonstrated that DNase 1L2 and DNase 2 play important roles in nuclear degradation in EK $[26,27]$, it may be interesting to investigate whether these enzymes contribute to nuclear loss during SCD. Taken together, the data suggest that SCD is a type of apoptosis-like programmed cell death as per the classification by Leist and Jaattela [6].

Shadow cells in PMX do not undergo degradation even in old lesions; instead, foreign body reaction around the nests as well as calcification and/or ossification may develop. This may correspond to the fact that normal hair does not show degradation but instead, falls out.

$S C D$ in $B C C$

BCC is a cutaneous tumor regarded as the most primitive follicular neoplasm. Although BCC and PMX mirror human follicular embryogenesis as reflected by their differential expression pattern of SOX9 and beta-catenin [45], BCC sometimes reveals matrical differentiation. A literature survey indicates that approximately 50 cases of BCC with matrical differ- 

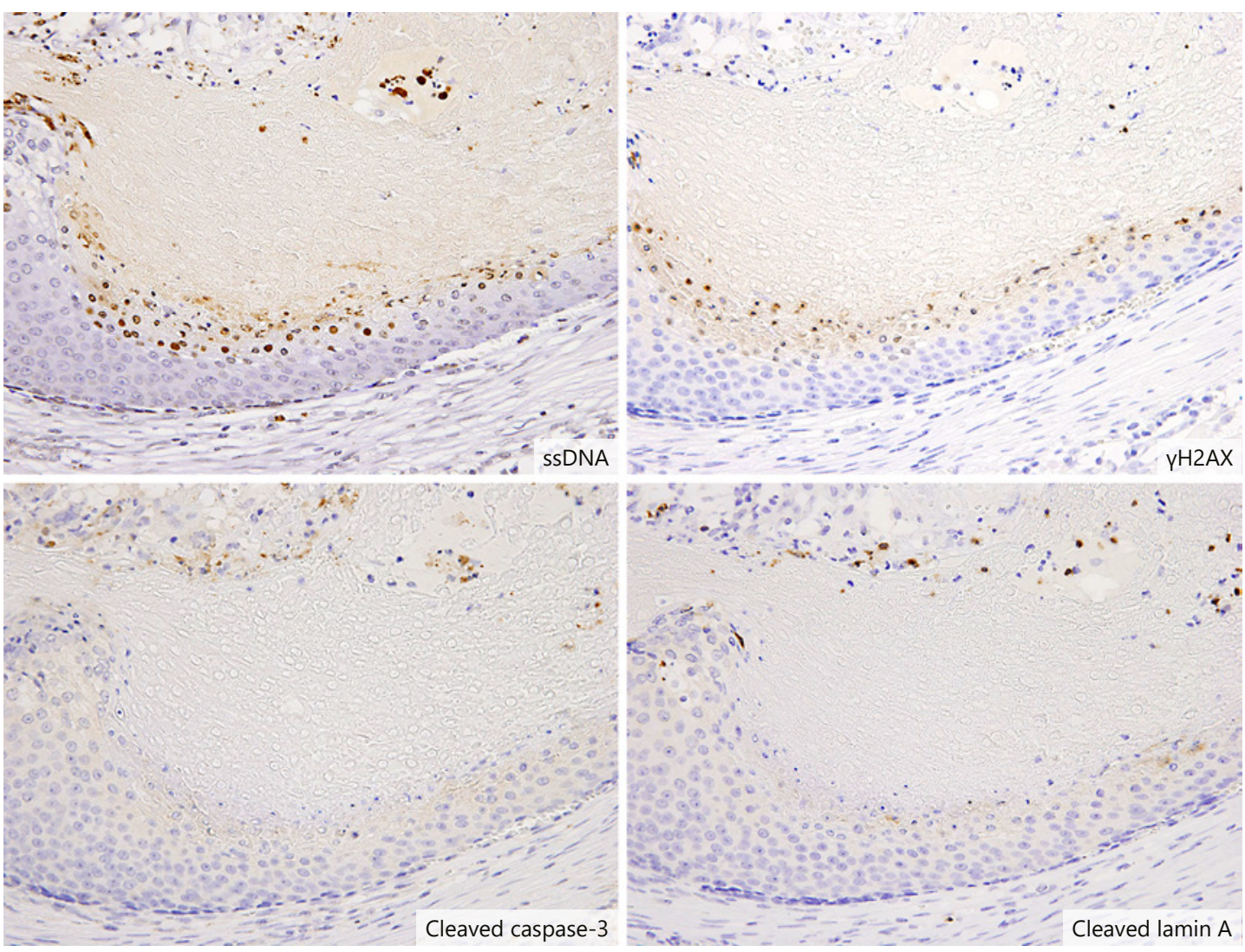

Fig. 5. Immunostaining for ssDNA, $\gamma \mathrm{H} 2 \mathrm{AX}$, cleaved caspase-3, and cleaved lamin A in pilomatricoma. The transitional cells are immunoreactive for the former two and negative for the latter two.

entiation have been reported [46-50]. Kyrpychova et al. [46] recently analyzed 22 cases, most of which (21 cases) contained SCNs with or without trichohyalin granules. They showed that nuclear accumulation of beta-catenin was observed in the areas with matrical differentiation, while in basaloid areas, the signal for nuclear beta-catenin was negative or focally positive. On the other hand, a case reported by Haskell et al. [50] showed no nuclear accumulation of beta-catenin. Originally, the expression pattern of beta-catenin in BCC without matrical differentiation was variable; for example, nuclear accumulation was frequent in infiltrative and morphea types, moderate in nodular and superficial types, and rarely observed in micronodular types of BCC [51]. This heterogeneity may reflect the variety in the differentiation directions in BCC.

\section{SCD in Extracutaneous Tumors}

SCNs are commonly found in cutaneous pilomatricoma, craniopharyngioma, and odontogenic cysts [38], while they are quite uncommon in extracutaneous tumors. From the standpoint of histogenesis, there are two groups of tumors with SCD: (a) gonadal or extragonadal teratomas and (b) visceral carcinomas. For teratomatous tumors, only several cases of testicular or ovarian teratomas containing SCNs have been reported [52-55]. In these cases, SCD is regarded as one of the components showing multi-directional differentiation. On the other hand, there have been 16 reported cases of visceral carcinomas with SCD, with the exception of teratomatous tumors. The primary site of these tumors includes ovary [56-58], endometrium $[59,60]$, colon $[59,61]$, gallbladder [62], urinary bladder $[63,64]$, stomach 


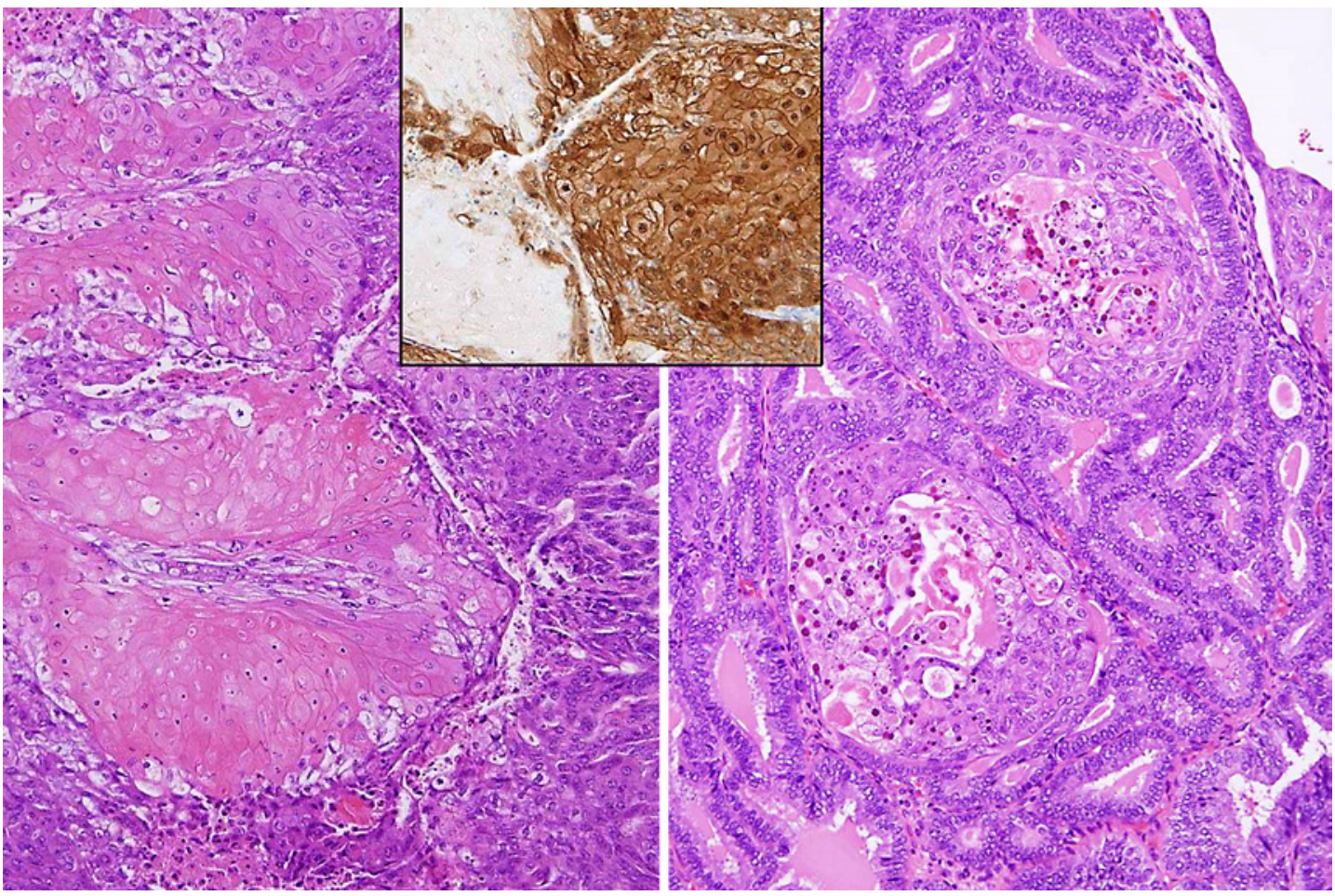

Fig. 6. Endometrioid carcinoma showing shadow cell differentiation from squamoid morule (left) and numerous trichohyaline granules in morule (right) (H\&E stain). Inset Nuclear accumulation of beta-catenin in squamoid morule.

[65], and lung [66]. Histologically, all these cases except for one (gallbladder carcinoma) are adenosquamous carcinomas, adenocarcinomas with squamous metaplasia (adenoacanthomas), urothelial carcinomas with squamous differentiation, or squamous cell carcinomas, suggesting that shadow cells are derived from squamous/squamoid components. The incidence, detailed morphogenesis, and molecular pathogenesis had not been investigated until recently, while the incidence of SCD in endometrial carcinoma was reported by two groups in 2015. Zamecnik et al. [67] reported that SCD was observed in 15.3\% of endometrioid adenocarcinomas, and our data indicated SCD was present in 24\% of endometrial adenoacanthomas (adenocarcinomas with squamous metaplasia) [68]. The discrepancy in the incidence between the two reports may be due to differences in the histological type of the examined cases. SCNs had previously been regarded as conventional keratinization in routine diagnostic practice except for the field of dermatopathology, while in actual fact, it seems that SCD is not as uncommon as previously estimated.

Squamoid morules had been regarded as immature squamous metaplasia, while recent reports have shown that these two are different from each other; a morule is characterized by expression of CD10 and CDX-2, nuclear accumulation of beta-catenin, and mutation of the beta-catenin gene [69-71], while squamous metaplasia is not [71]. We demonstrated that shadow cells were derived from squamoid morules in endometrial adenoacanthomas [68] (Fig. 6), which established a link between squamoid morules and basaloid cells in PMX as precursors of shadow cells sharing common characteristics such as nuclear accumulation of beta-catenin and expression of CD10. In addition, we recently encountered a previously undescribed case of endometrioid carcinoma with squamoid morules containing numerous trichohyalin granules (Fig. 6) (unpublished observation). Taken together, it is suggested that 
squamoid morules do not undergo EK, but have the potential to differentiate into hair. This new knowledge on squamoid morules may support the view that SCD and EK are different modes of cell death.

\section{Conclusion}

SCD is observed not only in PMX, but also in other tumors such as BCC, gonadal or extragonadal teratomas, and various visceral carcinomas. The precursors of shadow cells, such as basaloid (matrical) cells and squamoid morules, are characterized by nuclear accumulation of beta-catenin and expression of CD10. SCD has been regarded as a variant of keratinization, while it is distinct from EK and TK from the standpoint of cell death/differentiation. On the other hand, SCD may be different from, but partly similar to, apoptosis, and these two may compose a sequential chain of modes of cell death pathways. Compared to EK, detailed modes of cell death in SCD remain to be clarified, so further studies will be necessary to elucidate the molecular mechanism of SCD.

\section{Statement of Ethics}

This work was carried out according to the criteria required by the institutional ethical review board.

\section{Disclosure Statement}

The author declares that there is no conflict of interest in this study.

\section{References}

1 Melino G, Knight RA, Nicotera P: How many ways to die? How many different modes of cell death? Cell Death Differ 2005;12:1457-1462.

2 Kroemer G, El-Deiry WS, Golstein P, et al: Classification of cell death: recommendations of the Nomenclature Committee on Cell Death. Cell Death Differ 2005;12:1463-1467.

3 Kroemer G, Galluzzi L, Vandenabeele P, et al: Classification of cell death: recommendations of the Nomenclature Committee on Cell Death 2009. Cell Death Differ 2009;16:3-11.

4 Galluzzi L, Vitale I, Abrams JM, et al: Molecular definitions of cell death subroutines: recommendations of the Nomenclature Committee on Cell Death 2012. Cell Death Differ 2012;19:107-120.

5 Galluzzi L, Vitale I, Aarpmspm SA, et al: Molecular mechanisms of cell death: recommendations of the Nomenclature Committee on Cell Death 2018. Cell Death Differ 2018;25:486-541.

6 Leist M, Jaattela M: Four deaths and a funeral: from caspases to alternative mechanisms. Nat Rev Mol Cell Biol 2001;2:589-598.

7 Counis MF, Chaudun E, Arruti C, Oliver L, Sanwal M, Courtois Y, Torriglia A: Analysis of nuclear degradation during lens cell differentiation. Cell Death Differ 1998;5:251-261.

8 Testa U: Apoptotic mechanisms in the control of erythropoiesis. Leukemia 2004;18:1176-1199.

9 Nakamura T: Comparative immunohistochemical analyses on the modes of cell death in epidermal cyst, trichilemmal cyst and pilomatricoma. Am J Dermatopathol 2011;33:78-83.

10 Ackerman AB, De Viragh PA, Chongchitnant N: Neoplasms with follicular differentiation. Philadelphia, Lea \& Febiger, 1993; pp 35-102.

11 Gandarillas A, Goldsmith LA, Gschmeisser S, Leigh IM, Watt PM: Evidence that apoptosis and terminal differentiation of epidermal keratinocytes are distinct process. Exp Dermatol 1999;8:71-79.

12 Lippens S, Denecker G, Ovaere P, Vandenabeele P, Declercq W: Death penalty for keratinocytes: apoptosis versus cornification. Cell Death Differ 2005;12:1497-1508.

13 Geske FJ, Gerschenson LE: The biology of apoptosis. Hum Pathol 2001;32:1029-1038. 
14 Wolf BB, Green DR: Suicidal tendencies: apoptotic cell death by caspase family proteinases. J Biol Chem 1999; 274:20049-20052.

15 Broker LE, Kruyt FAE, Giaccone G: Cell death independent of caspases: a review. Clin Cancer Res 2005;11: 3155-3162.

16 Compton MM: A biochemical hallmark of apoptosis: internucleosomal degradation of the genome. Cancer Metastasis Rev 1992;11:105-119.

17 Nagata S, Nagase H, Kawane K, Mukae N, Fukuyama H: Degradation of chromosomal DNA during apoptosis. Cell Death Differ 2003;10:108-116.

18 Gavrieli Y, Sherman Y, Ben-Sasson SA: Identification of programmed cell death in situ via specific labeling of nuclear DNA fragmentation. J Cell Biol 1992;119:493-501.

19 Nakamura T, Sakai T, Hotchi M: Histochemical demonstration of DNA double strand breaks by in situ 3'-tailing reaction in apoptotic endometrium. Biotech Histochem 1995;70:33-39.

20 Naruse I, Keino H, Kawarada Y: Antibody against single-stranded DNA detects both programmed cell death and drug-induced apoptosis. Histochemistry 1994;101:73-78.

21 Caulin C, Salvesen GS, Oshima RG: Caspase cleavage of keratin 18 and reorganization of intermediate filaments during epithelial cell apoptosis. J Cell Biol 1997;138:1379-1394.

22 Mashima T, Naito M, Tsuruo T: Caspase-mediated cleavage of cytoskeletal actin plays a positive role in the process of morphological apoptosis. Oncogene 1999;18:2423-2430.

23 Oshima RG: Apoptosis and keratin intermediate filaments. Cell Death Differ 2002;9:486-492.

24 Kuo LJ, Yang LX: Gamma-H2AX - a novel biomarker for DNA double strand breaks. In Vivo 2008;22:305-309.

25 Lippens S, Hoste E, Vandenabeele PV, Agostinis P, Declercq W: Cell death in the skin. Apoptosis 2009;14:549569.

26 Fischer H, Eckhart L, Mildner M, Jaeger K, Buchberger M, Ghannadan M, Tschachler E: DNase1L2 degrades nuclear DNA during corneocyte formation. J Invest Dermatol 2007;127:24-30.

27 Fisher H, Buchberger M, Napirei M, Tschachler E, Eckhart L: Inactivation of DNase1L2 and DNase2 in keratinocytes suppresses DNA degradation during epidermal cornification and results in constitutive parakeratosis. Sci Rep 2017;7:6433.

28 Eckhart L, Lippens S, Tschachler E, Declercq W: Cell death by cornification. Biochim Biophys Acta 2013;1833: 3471-3480.

29 Eckert RL, Stumiolo MT, Broome AM, Ruse M, Rorke A: Transglutaminase function in epidermis. J Invest Dermatol 2005;124:481-492.

30 Denecker G, Hoste E, Gilbert B, Hochepied T, Ovaere P, Lippens S, Van den Broecke C, Van Damme P, D’Herde K, Hachem JP, Borgonie G, Presland RB, Schoonjans L, Libert C, Vandekerckhove J, Gevaert K, Vandenabeele P, Declercq W: Caspase-14 protects against epidermal UVB photodamage and water loss. Nat Cell Biol 2007;9: 666-674.

31 Lippens S, VandenBroecke C, Van Damme E, Tschachler E, Vandenabeele P, Declercq W: Caspase-14 is expressed in the epidermis, the choroid plexus, the retinal pigment epithelium and thymic Hassall's bodies. Cell Death Differ 2003;10:257-259.

32 Denecker G, Ovaere P, Vandenabeele P, Declercq W: Caspase-14 reveals its secrets. J Cell Biol 2008;180:451458.

33 Ishida-Yamamoto A, Igawa S: The biology and regulation of corneodesmosomes. Cell Tissue Res 2015;477482.

34 Ishida-Yamamoto A, Kishibe M: Involvement of corneodesmosome degradation and lamellar granule transportation in the desquamation process. Med Mol Morphol 2011;44:1-6.

35 Caubet C, Jonca N, Brattsand M, Guerrin M, Bernard D, Schmidt R, Egelrud T, Simon M, Serre G: Degradation of corneodesmosome proteins by two serine proteases of the kallikrein family, SCTE/KLK5/hK5 and SCCE/ KLK7/hK7. J Invest Dermatol 2004;122:1235-1244.

36 Bayer-Garner IB, Sanderson RD, Smoller BR: Syndecan-1 is strongly expressed in the anagen hair follicle outer root sheath and in the dermal papilla but expression diminishes with involution of the hair follicle. Am J Dermatopathol 2002;24:484-489.

37 Malgouries S, Thibaut S, Bernard BA: Proteoglycan expression patterns in human hair follicle. Br J Dermatol 2008;158:234-242.

38 Hassanein AM, Glanz SM, Kessler HP, Eskin TA, Liu C: Beta-catenin is expressed aberrantly in tumors expressing shadow cells. Pilomatricoma, craniopharyngioma and calcifying odontogenic cyst. Am J Clin Pathol 2003;120: 732-736.

39 Kim YS, Shin DH, Choi JS, Kim K-H: The immunohistochemical patterns of beta-catenin expression in pilomatricoma. Ann Dermatol 2010;22:284-289.

40 Xia J, Urabe K, Moroi Y, Koga T, Duan H, Li Y, Furue M: Beta-catenin mutation and its nuclear localization are confirmed to be frequent causes of Wnt signaling pathway activation in pilomatricomas. J Dermatol Sci 2006; 41:67-75.

41 Brembeck FH, Rosario M, Birchmeier W: Balancing cell adhesion and Wnt signaling, the key role of betacatenin. Curr Opin Genet Dev 2006;16:51-59.

42 Nakamura T: A reappraisal on the modes of cell death in pilomatricoma. J Cutan Pathol 1999;26:125-129. 
Nakamura: Shadow Cell Differentiation

43 Kurokawa I, Yamanaka K, Senba Y, Sugisaki H, Tsubura A, Kimura T, Mizutani H: Pilomatricoma can differentiate not only towards hair matrix and hair cortex, but also follicular infundibulum, outer root sheath and hair bulge. Exp Dermatol 2009;18:734-737.

44 Kaddu S, Soyer HP, Hoedl S, Kerl H: Morphological stages of pilomatricomas. Am J Dermatopathol 1996;18: 333-338.

45 Krahl D, Sellheyer K: Basal cell carcinoma and pilomatrixoma mirror human follicular embryogenesis as reflected by their differential expression patterns of SOX9 and beta-catenin. Br J Dermatol 2010;162:12941301.

46 Kyrpychova L, Carr RA, Martinek PM, Vanecek T, Perrett R, Chottova-Dvorakova M, Zamecnik M, Hadravsky L, Michal M, Kazakov DV: Basal cell carcinoma with metrical differentiation. Clinicopathologic, immunohistochemical, and molecular biological study of 22 cases. Am J Surg Pathol 2017;41:738-749.

47 Maroun C, Alam E, Khalifeh I, Abbas O, Moukarbel RV: Nasal basal cell carcinoma with matrical differentiation: risk of metastasis and impact on management. Head Neck Pathol 2017;11:228-233.

48 All F, Brown A, Gottwald L, Thomas J: Basal cell carcinoma with matrical differentiation in a transplant patient: a case report and review of the literature. J Cutan Pathol 2005;32:445-448.

49 Kim SH, Lee M-G, Lee KG: Basal cell carcinoma with matrical differentiation. Yonsei Med J 2003;44:523-525.

50 Haskell HD, Haynes HA, McKee PH, Redston M, Granter SR, Lazar AJF: Basal cell carcinoma with matrical differentiation: a case study with analysis of beta-catenin. J Cutan Pathol 2005:32:245-250.

51 El-Bahrawy M, El-Masry N, Alison M, Poulsom R, Fallowfield M: Expression of beta-catenin in basal cell carcinoma. Br J Dermatol 2003;148:964-970.

52 Alfsen GC, Strom EH: Pilomatrixoma of the ovary: a rare variant of mature teratoma. Histopathology 1998;32: 182-183.

53 Minkowitz G, Lee M, Minkowitz S: Pilomatricoma of the testicle. An ossifying testicular tumor with hair matrix differentiation. Arch Pathol Lab Med 1995;119:96-99.

54 Ulbright TM, Srigley JR: Dermoid cyst of the testis: a study of five postpubertal cases, including a pilomatrixoma-like variant, with evidence supporting its separate classification from mature testicular teratoma. Am J Surg Pathol 2001;25:788-793.

55 Zamecnik M, Mukensnabl P, Curik R, Michal M: Shadow cell differentiation in testicular teratomas. A report of two cases. Cesk Patol 2005;41:102-106.

56 Zamecnik M, Jando D, Kascak P: Ovarian basaloid carcinoma with shadow cell differentiation. Case Reports Pathol 2014;ID 391947.

57 Fang J, Keh P, Katz L, Rao MS: Pilomatrixoma-like endometrioid adenosquamous carcinoma of the ovary with neuroendocrine differentiation. Gynecol Oncol 1996;61:291-293.

58 Lalich D, Tawfik O, Chapman J, Fraga G: Cutaneous metastasis of ovarian carcinoma with shadow cells mimicking a primary pilomatrical neoplasm. Am J Dermatopathol 2010;32:500-504.

59 Zamecnik M, Michal M: Shadow cell differentiation in tumours of the colon and uterus. Zentralbl Pathol 1995; 140:421-426.

60 Squillaci S, Marchione R, Piccolomini M, Chiudinelli M, Fiumano E, Ungari M: Uterine endometrioid adenocarcinoma with extensive pilomatrixoma-like areas. Pathologica 2013;105:8-10.

61 Nakayama H, Kimura A, Okumichi T, Miyazaki E, Kajihara H, Enzan H: Metaplastic shadow cells in rectal adenocarcinoma: Report of a case with immunohistochemical study. Jpn J Clin Oncol 1997;27:427-432.

62 Zamecnik M, Michal M, Mukensnabl P: Pilomatrixoma-like visceral carcinomas. Histopathology 1998;33:395.

63 Zamecnik M, Michal M, Mukensnabl P: Shadow cells in extracutaneous locations. Arch Pathol Lab Med 1996; 120:426-428.

64 Nakamura T: Bladder carcinoma with shadow cell differentiation: a case report with immunohistochemical analyses. Int J Clin Exp Pathol 2012;5:840-844.

65 Nakamura T: Gastric carcinoma with shadow cell differentiation at metastatic site of lymph nodes. Hum Pathol Case Rep 2017;7:19-22.

66 Garcia-Escudero A, Navarro-Bustos G, Jurado-Escamez P, Rios-Martin J, Gonzalez-Campora R: Primary squamous cell carcinoma of the lung with pilomatricoma-like features. Histopathology 2002;40:201-202.

67 Zamecnik M, Bartos P, Kascak P: Shadow cell differentiation in endometrioid carcinomas of the uterus. Its frequent occurrence and beta-catenin expression. Cesk Patol 2015;51:123-126.

68 Nakamura T: Shadow cell differentiation from squamoid morules in endometrial adenoacanthoma. Int J Clin Exp Pathol 2015;8:13120-13124.

69 Ueo T, Kashima K, Daa T, Kondo Y, Sasaki A, Yokoyama S: Immunohistochemical analysis of morules in colonic neoplasms: morules are morphologically and qualitatively different from squamous metaplasia. Pathobiology 2005;72:269-278.

70 Chiarelli S, Buritica C, Litta P, Ciani S, Guarch R, Nogales FF: An immunohistochemical study of morules in endometrioid lesions of the female genital tract: CD10 is a characteristic marker of morular metaplasia. Clin Cancer Res 2006;12:4251-4256.

71 Houghton 0, Connolly LE, McCluggage WG: Morules in endometrioid proliferations of the uterus and ovary consistently express the intestinal transcription factor CDX2. Histopathology 2008;53:156-165. 